\title{
Androgen receptor gene polymorphisms lean mass and performance in young men
}

\author{
Amelia Guadalupe-Grau, ${ }^{1}$ F Germán Rodríguez-González, ,,3 Cecilia Dorado, \\ Hugo Olmedillas, ${ }^{1}$ Teresa Fuentes, ${ }^{1}$ Jorge Pérez-Gómez, ${ }^{1}$ Safira Delgado-Guerra, \\ Germán Vicente-Rodríguez, ${ }^{1}$ Ignacio Ara, ${ }^{1}$ Borja Guerra, ${ }^{1}$ Rafael Arteaga-Ortiz, ${ }^{4}$ \\ José A L Calbet, ${ }^{1}$ B Nicolás Díaz-Chico ${ }^{2,3}$
}

${ }^{1}$ Department of Physical

Education, University of Las

Palmas de Gran Canaria,

Campus Universitario de

Tafira s/n, Las Palmas de Gran Canaria, 35017, Spain

${ }^{2}$ Department of Biochemistry and Physiology, Universidad

de Las Palmas de Gran

Canaria, Las Palmas de Gran

Canaria, Spain

${ }^{3}$ Canary Islands Cancer

Research Institute (ICIC),

Las Palmas de Gran Canaria

Canary Islands, Spain

${ }^{4}$ Department of Physics,

University of Las Palmas

de Gran Canaria, Campus

Universitario de Tafira $s / n$,

Las Palmas de Gran Canaria

35017, Spain

\section{Correspondence to}

Jose A L Calbet,

Departamento de Educación

Física, Campus Universitario

de Tafira, 35017 Las Palmas

de Gran Canaria, Canary

Island, Spain;

lopezcalbet@gmail.com

Accepted 3 July 2009

Published Online First

16 July 2009

\section{ABSTRACT}

The exon-1 of the androgen receptor $(A R)$ gene contains two repeat length polymorphisms which modify either the amount of $A R$ protein inside the cell $\left(G G N_{n^{\prime}}\right.$ polyglycine) or its transcriptional activity $\left(C A G_{n^{\prime}}\right.$ polyglutamine). Shorter $C A G$ and/or $G G N$ repeats provide stronger androgen signalling and vice versa. To test the hypothesis that $C A G$ and $G G N$ repeat $A R$ polymorphisms affect muscle mass and various variables of muscular strength phenotype traits, the length of $C A G$ and $G G N$ repeats was determined by PCR and fragment analysis and confirmed by DNA sequencing of selected samples in 282 men (28.6 \pm 7.6 years). Individuals were grouped as $C A G$ short $\left(C A G_{S}\right)$ if harbouring repeat lengths of $\leq 21$ and $C A G$ long $\left(C A G_{L}\right)$ if $C A G>21$. GGN was considered short $\left(G G N_{S}\right)$ or long $\left(G G N_{1}\right)$ if $G G N \leq 23$ or $>23$, respectively. No significant differences in lean body mass or fitness were observed between the $C A G_{S}$ and $C A G_{L}$ groups, or between $G G N_{S}$ and $G G N$, groups, but a trend for a correlation was found for the GGN repeat and lean mass of the extremities $(r=-0.11, p=0.06)$. In summary, the lengths of $C A G$ and $G G N$ repeat of the $A R$ gene do not appear to influence lean mass or fitness in young men.

\section{INTRODUCTION}

Muscle mass and strength, as well as aerobic fitness $\left(\mathrm{VO}_{2} \mathrm{max}\right)$ are related to health and mortality. ${ }^{1}$ Muscle mass and strength is determined by environmental factors, principally endocrine, nutritional and mechanical loading, and by the genetic background. ${ }^{2}$ Gene polymorphisms, like those encoding for the insulin-like grow th factor-1 $(I G F-1),{ }^{3}$ type I collagen (COL1A1), ${ }^{4}$ ciliary neurotrophic factor $(C N T F),{ }^{5}$ interleukin-6 (IL-6), ${ }^{6}$ the vitamin $\mathrm{D}$ receptor $(V D R),{ }^{7} I G F-2,{ }^{8}$ resistin $(R E T N)^{9}$ and androgen receptor $(A R),{ }^{10}$ have an influence on either muscle mass or strength.

The $A R$ gene is located to the $\mathrm{X}$ chromosome (q11.2-q12), and contains eight exons. The exon 1 contains a polyglutamine tract encoded by $C A G$ repeats and a polyglycine tract (GGN) encoded by $(G G T)_{3} G G G(G G T)_{2}(G G C)_{n}$. Polymorphictracts are close to the region encoding the transactivation-1 domain of the $A R$ protein. ${ }^{11}$ The CAG and GGN polymorphisms of the $A R$ gene are related to incidence of prostatic cancer, breast cancer, plasma hormone levels and other metabolic, cardiovascular and even mental diseases. ${ }^{12-15}$

The polyglutamine repeat has an average length of 22 a mino acids (range: 8-35). Short CAG repeats are associated with increased $A R$ transactivation activity and stronger transcriptional potential. ${ }^{16}$ The CAG polymorphisms are associated with the fat-free mass phenotype in healthy elders. ${ }^{10}$ However, it remains to be established if the $A R$ polymorphism influences muscle mass and fitness in young adults.

The polyglycine repeat length of $A R$ ranges from 10 to $30 .{ }^{17}$ Short GGN repeats are associated with increased $A R$ protein content in cell cultures that may in turn enhance the response to androgen stimulation. ${ }^{18}$ It remains unknown if a short GGN repeat number is associated to increased muscle mass or strength in humans.

The aim of this study was to determine if AR polymorphisms are associated to muscle mass and physical fitness in adult men. We tested the hypothesis of whether men with short CAG and/ or short GGN repeats have greater fat-free mass and muscle mass, and, therefore, greater strength and muscle power, than those harbouring long $C A G$ and/or long GGN repeats. Since studies in cell culture and animal models have shown that androgen- $A R$ signalling pathway increases the expression of slow-twitch-specific skeletal muscle proteins leading to a more oxidative phenotype, ${ }^{19}$ we also studied whether $A R$ polymorphisms have an effect on aerobic power $\left(\mathrm{VO}_{2} \mathrm{max}\right)$ in humans. This information may be useful to elaborate genetic profiles like those recently proposed by Lucia et a ${ }^{20-22}$ to explain individual variations in human physical performance.

\section{METHODS \\ Subjects}

Two-hundred and eighty-two Caucasian men participated in the study. They were recruited from physically active university students, sports clubs and local police officers in Gran Canaria (Spain). Recruitment started in February 2003 and extended to June 2007. The health status of each participant was established by a medical history and physical examination. Subjects taking any kind of medications or having any chronic disease or hypertension were excluded. The study was performed in accordance with the Helsinki Declaration of 1975 as regards the conduct of clinical research, being approved by the Ethical Committee of the University of Las Palmas de Gran Canaria. All volunteers provided their written informed consent before participation in the study. 


\section{Tests}

Tests were carried out over 4 days. The first testing day started with a 20-ml blood sample which was obtained from an antecubital vein in the supine position, between 7:30 and 8:30. Body composition, jumping performance and maximal isometric force was tested on the second day. The last 2 days were used to assess sprint performance and anaerobic capacity, as well as maximal aerobic power $\left(\mathrm{VO}_{2} \mathrm{max}\right)$.

\section{Body composition}

Whole body composition was assessed by dual-energy x-ray absorptiometry (DXA; ODR-1500; Hologic Corp., software version 7.10, Waltham, Massachusetts, USA) as reported in Perez-Gomez et al. ${ }^{23}$ Upper and lower limb lean mass (kg) was calculated from the regional analysis of the whole body scan, ${ }^{24}$ 25 which gives a valid and reliable estimate of muscle mass in the extremities. ${ }^{26}$

\section{Vertical jump performance and running sprint tests}

The forces generated during vertical jumps were measured with a force platform (Kistler, Winterthur, Switzerland), as reported in Ara et al. ${ }^{27}$ Two kinds of jumps were performed: squat jump, in which countermovement was not permitted, and countermovement jump, from standing position subjects were asked to perform a countermovement, intending to reach knee bending angles of around $90^{\circ}$ just before impulsion.

Subjects performed three maximal indoor 30-m running sprint trials to assess running speed with photocells (General ASDE, Valencia, Spain). Each sprint was separated by at least 5 -min rest, and the best performance was recorded. ${ }^{28}$

\section{Anaerobic capacity}

An all-out 300-m running test was used to estimate the anaerobic capacity, since the anaerobic metabolic pathways contribute more than $50 \%$ to the overall energy expenditure during all-out exercise tests with a duration between 30 and 60 s. ${ }^{29}$ The test was performed on a 400 -m track; the time was recorded manually with a digital stopwatch.

\section{Aerobic maximal power}

The maximal oxygen uptake $\left(\mathrm{VO}_{2} \max \right)$ was estimated using the maximal multistage 20 -m shuttle run. ${ }^{30}$ The time during which the subjects were able to run for was recorded to calculate $\mathrm{VO}_{2} \max$.

\section{CAG and GGN repeat polymorphisms}

DNA was extracted from blood samples (200 $\mu$ l) using High Pure PCR Template Preparation Kits (Roche Applied Science). To determine the length of the $C A G$ and GGN repeats, the corresponding regions located on the exon 1 of the $A R$ gene (Genbank accession no. M27423) were amplified using two pairs of primers whose sequences have been previously reported..$^{13}$ One primer from each pair was marked with fluorescent dye (FAM or VIC). Amplification was performed in a 25 - $\mathrm{\mu l}$ reaction volume, containing $50 \mathrm{ng}$ of genomic DNA, 200 $\mu \mathrm{M}$ of each deoxynucleotide triphosphate, $1 \times$ FastStart Taq DNA polymerase Buffer (Roche Applied Science, Mannheim, Germany), 1× GC-rich solution buffer (Roche Applied Science) and $1 \mathrm{U}$ of FastStart Taq DNA polymerase (Roche Applied Science). The concentration of each pair of primers was 1.2 and $1.5 \mu \mathrm{M}$ for the amplification of the CAG and GGN repeats, respectively. PCR conditions were 30 cycles of $95^{\circ} \mathrm{C}$ for $45 \mathrm{~s}, 56^{\circ} \mathrm{C}$ for $30 \mathrm{~s}$ and $72^{\circ} \mathrm{C}$ for $30 \mathrm{~s}$ for CAG amplification; 30 cycles of $95^{\circ} \mathrm{C}$ for $1 \mathrm{~min}, 55^{\circ} \mathrm{C}$ for $2 \mathrm{~min}$ and $72^{\circ} \mathrm{C}$ for
2 min for GGN amplification. Each PCR was initiated with a denaturation step at $95^{\circ} \mathrm{C}$ for $5 \mathrm{~min}$ and terminated with an extension step at $72^{\circ} \mathrm{C}$ for $5 \mathrm{~min}$. The PCR product was diluted 1:100 in distilled water, and $1 \mu \mathrm{l}$ of the dilution was mixed with $10 \mu \mathrm{l}$ of formamide and $0.3 \mu \mathrm{l}$ of GeneScan 500 LIZ Size Standard (Applied Biosystems, Warrington, UK), denatured at $98^{\circ} \mathrm{C}$ for $5 \mathrm{~min}$ and cooled on ice. Fragment separation was performed by automated capillary electrophoresis, using an ABI Prism 3100 Genetic Analyzer (Applied Biosystems), and the length was determined with GeneScan Analysis Software (version 3.7; Applied Biosystems). Internal standards supplied by the manufacturer were used for quality control. We blindly repeated the genotype analysis in 54 of the samples, and the results were completely coincident. The fragments size was confirmed by sequencing 48 DNA samples harbouring different size alleles for both repeats by using the BigDye Terminator Sequencing Kit (Applied Biosystem) at University of Las Palmas Sequencing Facility. Genotyping was performed specifically for research purposes based on the hypothesis that the aforementioned polymorphisms may influence $\mathrm{VO}_{2}$ max, lean mass and muscle strength. The genotype data of the subjects were not previously analysed for other non-research purposes and as such were not presented a posteriori for the present paper. The researchers in charge of genotyping were totally blinded to the subjects' identities, that is, blood samples were tracked

Table 1 Subject's body composition, anthropometrics, physical activity and fitness (mean \pm SD)

\begin{tabular}{|c|c|c|}
\hline & Mean \pm SD & $\mathbf{n}$ \\
\hline Age (years) & $28.8 \pm 7.6$ & 282 \\
\hline Height (cm) & $176.8 \pm 5.5$ & 282 \\
\hline Body mass (kg) & $79.2 \pm 10.3$ & 282 \\
\hline Percentage of body fat & $19.3 \pm 7.3$ & 282 \\
\hline Lean body mass (kg) & $59.5 \pm 5.6$ & 282 \\
\hline Lean body mass $/ \mathrm{Ht}^{2}\left(\mathrm{~kg} / \mathrm{m}^{2}\right)$ & $19.0 \pm 1.5$ & 282 \\
\hline Lean mass arms (kg) & $6.7 \pm 0.9$ & 282 \\
\hline Lean mass legs $(\mathrm{kg})$ & $19.8 \pm 2.2$ & 282 \\
\hline Lean mass extremities $(\mathrm{kg})$ & $26.4 \pm 2.9$ & 282 \\
\hline Lean mass arms $/ \mathrm{Ht}^{2}\left(\mathrm{~kg} / \mathrm{m}^{2}\right)$ & $2.1 \pm 0.3$ & 282 \\
\hline Lean mass legs $/ \mathrm{Ht}^{2}\left(\mathrm{~kg} / \mathrm{m}^{2}\right)$ & $6.3 \pm 0.6$ & 282 \\
\hline Lean mass extremities $/ \mathrm{Ht}^{2}\left(\mathrm{~kg} / \mathrm{m}^{2}\right)$ & $8.4 \pm 0.8$ & 282 \\
\hline Sports history (years) & $8.0 \pm 6.0$ & 282 \\
\hline \multicolumn{3}{|l|}{ Jumping tests } \\
\hline SJJH (m) & $0.292 \pm 0.054$ & 251 \\
\hline SJWmax (w) & $3409 \pm 536$ & 192 \\
\hline SJWmax/MML (w/kg) & $173 \pm 19$ & 192 \\
\hline CMJJH (m) & $0.331 \pm 0.061$ & 252 \\
\hline CMJWmax (w) & $3586 \pm 556$ & 194 \\
\hline CMJWmax/MML (w/kg) & $180 \pm 28$ & 192 \\
\hline \multicolumn{3}{|l|}{ Strength } \\
\hline MVC (kgf) & $106 \pm 21$ & 237 \\
\hline MVC/MML $(\mathrm{kgf} / \mathrm{kg})$ & $5.4 \pm 1.0$ & 237 \\
\hline \multicolumn{3}{|l|}{ Running test } \\
\hline $\mathrm{T}_{30 \mathrm{~m}}(\mathrm{~s})$ & $4.53 \pm 0.29$ & 272 \\
\hline $\mathrm{T}_{300 \mathrm{~m}}(\mathrm{~s})$ & $50.17 \pm 8.65$ & 271 \\
\hline \multicolumn{3}{|l|}{ Aerobic power } \\
\hline $\mathrm{VO}_{2} \max (\mathrm{ml} / \mathrm{kg} / \mathrm{ml})$ & $47.3 \pm 7.5$ & 267 \\
\hline
\end{tabular}

CMJJH, jumping height in countermovement jumps; CMJWmax, maximal power in countermovement jumps; CMJWmax/MML, maximal power in countermovement jumps per kg of muscle mass in the lower extremities; $\mathrm{Ht}$, height; MVC, maximal isometric force in the squatting position; SJJH, jumping height in squat jumps; SJWmax, maximal power in squat jumps; SJWmax/MML, maximal power in squat jumps per $\mathrm{kg}$ of muscle mass in the lower extremities (MML); $\mathrm{T}_{30 \mathrm{~m}}$ and $\mathrm{T}_{300 \mathrm{~m}}$ r running time in the 30 and $300 \mathrm{~m}$ running sprint, respectively. 

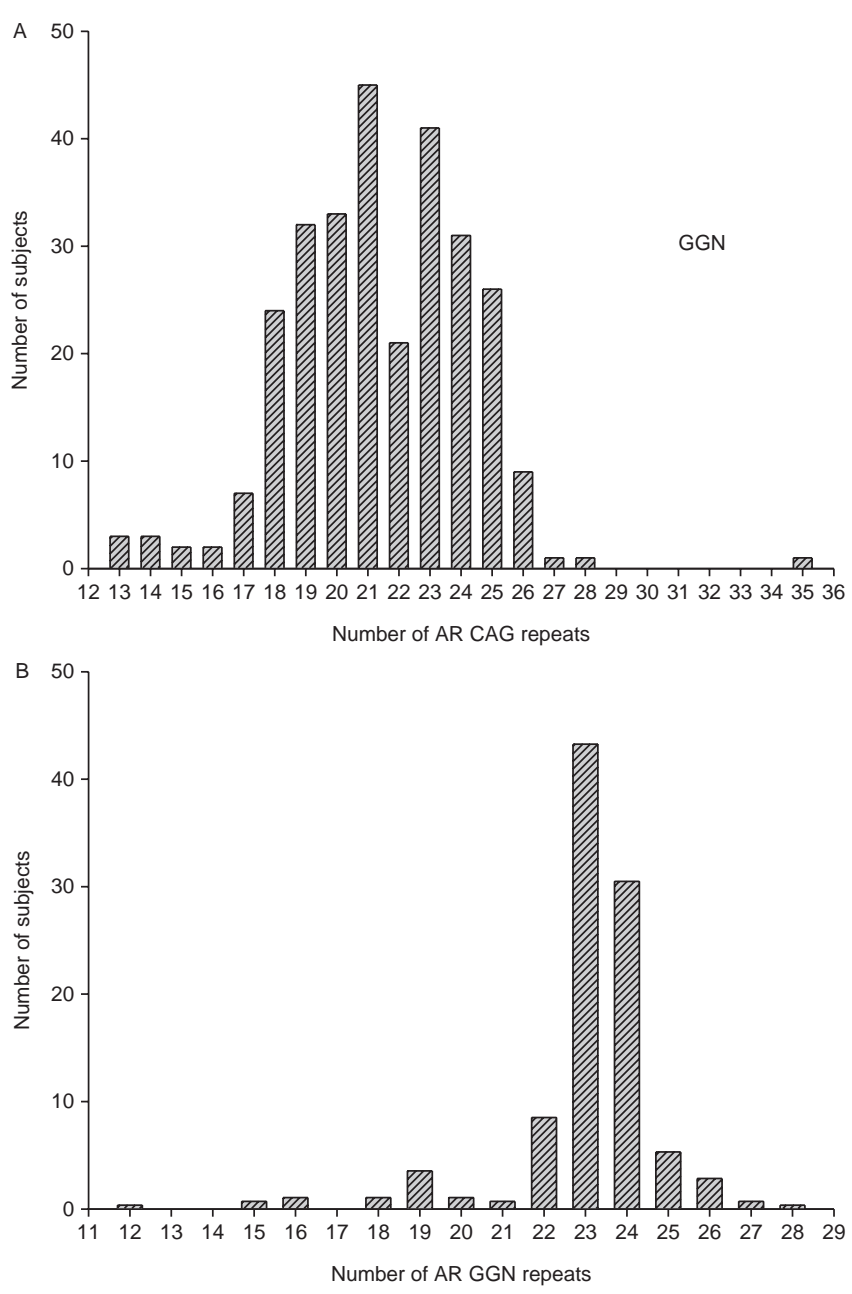

Figure 1 Histogram with the number of subjects with each (A) CAG and (B) GGN repeat number.

solely with code numbers, and personal identities were only made available to the main study researcher who was not involved in actual genotyping.

\section{Statistical analysis}

All variables were checked for normal distribution by the Kolmogorov-Smirnov test. When necessary, the analysis was done on logarithmically transformed data. The influence of $C A G$ and GGN repeat lengths on body composition and fitness was determined taking CAG and GGN repeat lengths as either continuous variables or as dichotomous variables with allele cut-off thresholds. The relationship between CAG and GGN as continuous variables with lean body mass and physical fitness variables was examined using linear regression analysis. The median value which resulted in the most balanced grouping was used as cut-off threshold. Thus, individuals were grouped as $C A G$ short $\left(C A G_{S} ; \mathrm{n}=151\right)$ if harbouring repeat lengths $\leq 21$ and $C A G$ long $\left(C A G_{L} ; \mathrm{n}=131\right)$ if harbouring repeat lengths $>21$. Subjects were ascribed to the GGN short $\left(G G N_{S} ; \mathrm{n}=170\right)$ group if harbouring repeat lengths of $\leq 23$; otherwise, they were included in the $G G N$ long $\left(G G N_{L} ; \mathrm{n}=112\right)$ group. In addition, the subjects were also grouped if having any of the following haplotype combinations: $C A G_{S}+G G N_{L}(\mathrm{n}=64), C A G_{L}+G G N_{S}$ $(\mathrm{n}=83), C A G_{L}+G G N_{L}(\mathrm{n}=48)$ and $C A G_{S}+G G N_{S}(\mathrm{n}=87)$.

Mean values were compared using analysis of variance with two factors (CAG and GGN lengths), each with two levels (short and long repeat number). Pairwise comparisons were tested for statistical significance using the Bonferroni post hoc test. Lean mass was corrected for differences in height by dividing muscle mass by height. ${ }^{2} 31$

\section{RESULTS}

Subject's body composition, anthropometrics, physical activity and fitness are reported in table 1 . The observed allele frequencies for $A R C A G$ and GGN repeat numbers in the studied subjects are presented in fig. 1. There were 17 different $C A G$ alleles (ranging from 13 to 35 repeats) and 14 GGN alleles, ranging from 12 to 28 repeats.

\section{CAG repeat polymorphism}

Subject's body composition, anthropometrics, physical activity and fitness in the $G G N_{S}$ and $G G N_{L}$ groups are reported in table 2 . The CAG polymorphism was not associated to any studied variable. No significant differences were found either in lean body mass or fitness between the $C A G_{S}$ and $C A G_{L}$ groups (table 2). There was no relationship between the length of the CAG repeat polymorphism and lean mass or physical fitness variables.

\section{GGN repeat polymorphism}

Subject's body composition, anthropometrics, physical activity and fitness in the $G G N_{S}$ and $G G N_{L}$ groups are reported in table 3. A trend for a significant inverse association between the logarithm of the length of the GGN polymorphism and the muscle mass of the extremities (MME) expressed as $\mathrm{kg} /$ height $^{2}$ was observed (MME=11.6-2.3×Lg GGN, $\mathrm{R}=0.11, \mathrm{p}=0.06)$. The length of the GGN repeat polymorphism did not correlate with any of the physical fitness variables assessed.

\section{Interaction between CAG and GGN repeat polymorphism}

The body composition, anthropometrics, physical activity and fitness of men grouped as $C A G_{L}+G G N_{L^{\prime}} C A G_{S}+G G N_{S^{\prime}}$ $C A G_{S}+G G N_{L}$ and $C A G_{L}+G G N_{S}$ are reported in table 4. Although men having the combination $C A G_{S}$ and $G G N_{S}$ jumped $9.0 \%$ higher than those having the combination $C A G_{L}$ and $G G N_{L}$ (table 4), this effect was not significant after accounting for multiple comparisons $(p=0.13)$. Differences between allele combinations in other physical fitness and lean mass variables were not significant, even without accounting for multiple comparisons.

\section{DISCUSSION}

This study shows that in physically active young men, AR polyglycine and polyglutamine repeat polymorphisms have no influence on lean mass or fitness when studied alone. Although the subjects with the combination $C A G_{S}$ and $G G N_{S}$ jumped higher than those with the combination of $C A G_{L}$ and $G G N_{L}$, this effect disappeared after accounting for multiple comparisons. However, we cannot rule out a potential type II error, implying that this effect needs to be verified in future studies.

In agreement with previous studies, we did not observe any association between height and length of the CAG repeat polymorphism in men. ${ }^{10}$ Although the subjects having a $C A G$ repeat number $>22$ had a $1.1 \%$ greater height ${ }^{2}$-adjusted lean body mass than the group with shorter alleles, this difference did not reach statistical significance. This is in contradiction to results from Walsh et a ${ }^{10}$ that reported a $2 \%$ greater lean body mass in the subjects with a CAG repeat number $\geq 22$, in a group of 294 men with a mean age of 73 years. The difference between both studies is likely due to the fact that our subjects 
Table 2 Body composition, anthropometrics, physical activity and fitness in men with $\mathrm{CAG}_{\mathrm{S}}$ and $\mathrm{CAG}_{\mathrm{L}}$ androgen receptor polymorphisms (mean \pm SD)

\begin{tabular}{|c|c|c|c|c|}
\hline & $\mathrm{CAG}_{\mathrm{S}}$ & n & $\mathrm{CAG}_{\mathrm{L}}$ & n \\
\hline Age & $28.3 \pm 7.6$ & 151 & $29.5 \pm 7.6$ & 131 \\
\hline Height $(\mathrm{cm})$ & $176.5 \pm 5.3$ & 151 & $177.1 \pm 5.8$ & 131 \\
\hline Body mass (kg) & $77.5 \pm 9.7$ & 151 & $78.8 \pm 10.9$ & 131 \\
\hline Percentage of body fat (\%) & $19.3 \pm 6.7$ & 151 & $19.3 \pm 8.0$ & 131 \\
\hline Lean body mass $(\mathrm{kg})$ & $59.1 \pm 5.8$ & 151 & $60.0 \pm 5.4$ & 131 \\
\hline Lean mass arms (kg) & $6.6 \pm 1.0$ & 151 & $6.8 \pm 0.9$ & 131 \\
\hline Lean mass legs $(\mathrm{kg})$ & $19.7 \pm 2.3$ & 151 & $19.8 \pm 2.0$ & 131 \\
\hline Lean mass extremities $(\mathrm{kg})$ & $26.3 \pm 3.1$ & 151 & $26.6 \pm 2.7$ & 131 \\
\hline Lean mass arms $/ \mathrm{Ht}^{2}\left(\mathrm{~kg} / \mathrm{m}^{2}\right)$ & $2.1 \pm 0.3$ & 151 & $2.2 \pm 0.3$ & 131 \\
\hline Lean mass legs $/ \mathrm{Ht}^{2}\left(\mathrm{~kg} / \mathrm{m}^{2}\right)$ & $6.3 \pm 0.6$ & 151 & $6.3 \pm 0.6$ & 131 \\
\hline Lean mass extremties $/ \mathrm{Ht}^{2}\left(\mathrm{~kg} / \mathrm{m}^{2}\right)$ & $8.4 \pm 0.9$ & 151 & $8.5 \pm 0.8$ & 131 \\
\hline Sports history (years) & $7.9 \pm 6.3$ & 145 & $8.1 \pm 5.3$ & 128 \\
\hline \multicolumn{5}{|l|}{ Jumping tests } \\
\hline SJJH (m) & $0.30 \pm 0.05$ & 133 & $0.29 \pm 0.05$ & 118 \\
\hline SJWmax (w) & $3387 \pm 544$ & 94 & $3429 \pm 530$ & 98 \\
\hline SJWmax/MML (w/kg) & $173.5 \pm 18.7$ & 94 & $172.1 \pm 19.2$ & 98 \\
\hline CMJJH (m) & $0.34 \pm 0.06$ & 134 & $0.32 \pm 0.06$ & 118 \\
\hline CMJWmax (w) & $3571 \pm 595$ & 96 & $3601 \pm 519$ & 98 \\
\hline CMJWmax/MML (w/kg) & $180.9 \pm 31.1$ & 94 & $178.6 \pm 25.1$ & 98 \\
\hline \multicolumn{5}{|l|}{ Strength } \\
\hline MVC (kg) & $105.8 \pm 22.0$ & 126 & $107.0 \pm 20.4$ & 111 \\
\hline MVC/MML (kg/kg) & $5.4 \pm 1.0$ & 126 & $5.4 \pm 1.0$ & 111 \\
\hline \multicolumn{5}{|l|}{ Running tests } \\
\hline $\mathrm{T}_{30 \mathrm{~m}}(\mathrm{~s})$ & $4.51 \pm 0.25$ & 147 & $4.56 \pm 0.33$ & 125 \\
\hline $\mathrm{T}_{300 \mathrm{~m}}(\mathrm{~s})$ & $49.7 \pm 7.1$ & 148 & $50.7 \pm 10.2$ & \\
\hline \multicolumn{5}{|l|}{ Maximal aerobic power } \\
\hline $\mathrm{VO}_{2} \max (\mathrm{ml} / \mathrm{kg} / \mathrm{min})$ & $47.0 \pm 7.9$ & 142 & $47.7 \pm 7.1$ & 124 \\
\hline
\end{tabular}

CMJJH, jumping height in countermovement jumps; CMJWmax, maximal power in countermovement jumps; CMJWmax/MML, maximal power in countermovement jumps per $\mathrm{kg}$ of muscle mass in the lower extremities; $\mathrm{Ht}$, height; MVC, maximal isometric force in the squatting position; SJJH, jumping height in squat jumps; SJWmax, maximal power in squat jumps; SJWmax/MML, maximal power in squat jumps per $\mathrm{kg}$ of muscle mass in the lower extremities (MML); $T_{30 m}$ and $T_{300 m^{\prime}}$, running time in the 30 and $300 \mathrm{~m}$ running sprint, respectively.

were much younger (29 years old) and had more appendicular muscle mass but lower height ${ }^{2}$-adjusted whole body lean mass than the subjects studied by Walsh et al, suggesting that with ageing men may increase trunk lean mass, due to changes in other components of the trunk lean mass apart from the muscle tissue as demonstrated by using potassium whole body counting. ${ }^{32}$ No significant differences in lean body mass, height or fitness were observed in men between the $C A G_{S}$ and $C A G_{L}$ groups. Like Walsh et al, ${ }^{10}$ we did not observe significant differences in appendicular muscle mass in men related to $C A G$ repeats.

In the present investigation, we have also examined the influence of the GGN repeat $A R$ polymorphism on muscle mass and physical fitness in healthy men. In agreement, with our hypothesis, there was a trend for an inverse relationship between the length of the GGN polymorphism and lean mass.

The possibility for an interaction between the CAG and GGN repeat polymorphism has not been previously studied. We have observed that the men having the microsatellite combination $C A G_{S}+G G N_{S}$ could jump higher than those harbouring the combination $C A G_{L}+G G N_{\mathrm{L}}$. The $C A G_{S}+G G N_{S}$ microsatellite combination has been associated to stronger androgen signalling ${ }^{11}{ }^{14}$; however, our results do not give clear support to the hypothesis that this combination may have a favourable influence in power-generating capacity of the skeletal muscles. Jumping performance is determined by body composition ${ }^{33}$ and factors that determine the speed of muscle activation and rate of force development, among which is critical the percentage of type II fibres. ${ }^{34}$ Performance in the 300 -m running test
Table 3 Body composition, anthropometrics, physical activity and fitness in men and women with $\mathrm{GGN}_{\mathrm{S}}$ and $\mathrm{GGN}_{\mathrm{L}}$ androgen receptor polymorphisms (mean \pm SD)

\begin{tabular}{|c|c|c|c|c|}
\hline & $\mathbf{G G N}_{\mathrm{S}}$ & $\mathbf{n}$ & $\mathbf{G G N}_{\mathrm{L}}$ & $n$ \\
\hline Age & $28.7 \pm 7.1$ & 170 & $29.1 \pm 8.4$ & 112 \\
\hline Height (cm) & $176.6 \pm 5.5$ & 170 & $177.1 \pm 5.6$ & 112 \\
\hline Body mass (kg) & $77.5 \pm 9.8$ & 170 & $79.1 \pm 10.9$ & 112 \\
\hline Percentage of body fat (\%) & $19.0 \pm 6.9$ & 170 & $19.7 \pm 7.9$ & 112 \\
\hline Lean body mass (kg) & $59.4 \pm 5.9$ & 170 & $59.8 \pm 5.2$ & 112 \\
\hline Lean mass arms $(\mathrm{kg})$ & $6.6 \pm 1.0$ & 170 & $6.7 \pm 0.9$ & 112 \\
\hline Lean mass legs $(\mathrm{kg})$ & $19.7 \pm 2.3$ & 170 & $19.9 \pm 2.1$ & 112 \\
\hline Lean mass extremities $(\mathrm{kg})$ & $26.3 \pm 3.0$ & 170 & $26.6 \pm 2.8$ & 112 \\
\hline Lean mass arms $/ \mathrm{Ht}^{2}\left(\mathrm{~kg} / \mathrm{m}^{2}\right)$ & $2.1 \pm 0.3$ & 170 & $2.1 \pm 0.3$ & 112 \\
\hline Lean mass legs $/ \mathrm{Ht}^{2}\left(\mathrm{~kg} / \mathrm{m}^{2}\right)$ & $6.3 \pm 0.6$ & 170 & $6.3 \pm 0.6$ & 112 \\
\hline Lean mass extremties $/ \mathrm{Ht}^{2}\left(\mathrm{~kg} / \mathrm{m}^{2}\right)$ & $8.4 \pm 0.8$ & 170 & $8.5 \pm 0.8$ & 112 \\
\hline Sports history (years) & $7.8 \pm 5.9$ & 165 & $8.3 \pm 5.8$ & 108 \\
\hline \multicolumn{5}{|l|}{ Jumping tests } \\
\hline SJJH (m) & $0.29 \pm 0.05$ & 150 & $0.29 \pm 0.06$ & 101 \\
\hline SJWmax (w) & $3394 \pm 519$ & 118 & $3432 \pm 566$ & 74 \\
\hline SJWmax/MML (w/kg) & $172.1 \pm 18.8$ & 118 & $174.0 \pm 19.2$ & 74 \\
\hline CMJJH (m) & $0.34 \pm 0.06$ & 151 & $0.32 \pm 0.06$ & 101 \\
\hline CMJWmax (w) & $3594 \pm 549$ & 120 & $3574 \pm 571$ & 74 \\
\hline CMJWmax/MML (w/kg) & $180.1 \pm 26.9$ & 118 & $179.0 \pm 30.2$ & 74 \\
\hline \multicolumn{5}{|l|}{ Strength } \\
\hline MVC (kg) & $107.6 \pm 22.0$ & 141 & $104.6 \pm 20.1$ & 96 \\
\hline MVC/MML $(\mathrm{kg} / \mathrm{kg})$ & $5.5 \pm 1.0$ & 141 & $5.3 \pm 1.0$ & 96 \\
\hline \multicolumn{5}{|l|}{ Running tests } \\
\hline $\mathrm{T}_{30 \mathrm{~m}}(\mathrm{~s})$ & $4.53 \pm 0.27$ & 162 & $4.54 \pm 0.32$ & 110 \\
\hline $\mathrm{T}_{300 \mathrm{~m}}(\mathrm{~s})$ & $49.7 \pm 7.3$ & 161 & $50.9 \pm 10.3$ & 110 \\
\hline \multicolumn{5}{|l|}{ Maximal aerobic power } \\
\hline $\mathrm{VO}_{2} \max (\mathrm{ml} / \mathrm{kg} / \mathrm{min})$ & $47.6 \pm 7.3$ & 161 & $46.9 \pm 7.8$ & 105 \\
\hline
\end{tabular}

CMJJH, jumping height in countermovement jumps; CMJWmax, maximal power in countermovement jumps; CMJWmax/MML, maximal power in countermovement jumps per $\mathrm{kg}$ of muscle mass in the lower extremities; $\mathrm{Ht}$, height; MVC, maximal isometric force in the squatting position; SJJH, jumping height in squat jumps; SJWmax, maximal power in squat jumps; SJWmax/MML, maximal power in squat jumps per $\mathrm{kg}$ of muscle mass in the lower extremities (MML); $\mathrm{T}_{30 \mathrm{~m}}$ and $\mathrm{T}_{300 \mathrm{~m}}$ running time in the 30 and $300 \mathrm{~m}$ running sprint, respectively.

depends not only in great part on the muscle mass ${ }^{35}$ but also on other factors which determine the contractile and metabolic properties of the muscles, such as a high percentage of fast-twitch (or type II) fibres and a high anaerobic capacity. ${ }^{29}$ ${ }^{36}$ In theory, the combination of $C A G_{S}+G G N_{S}$ may confer a functional advantage for tasks requiring muscle power, but additional studies are required to clarify this point.

It remains to be elucidated if $C A G_{S}$ and/or $G G N_{S}$ haplotypes are associated to an increased proportion of type II fibres and/ or enhanced anaerobic capacity. Animal studies indicate that increased androgen signalling may stimulate the expression of slow-twitch-specific skeletal muscle proteins while inhibiting fast-twitch-specific skeletal muscle proteins. ${ }^{19}$ However, there are no sex differences in muscle fibre types in humans, ${ }^{37}$ and 20 weeks treatment with testosterone enanthate did not change muscle fibres in men. ${ }^{38}$

\section{Competing interests None.}

Acknowledgements The authors thank José Navarro de Tuero for his excellent technical assistance.

Funding The study was supported by Ministerio de Educación y Ciencia (DEP2006-56076-C06-04/ACTI) and FEDER, Consejería de Educación, Cultura y Deportes del Gobierno de Canarias (2006/179 0001 and FEDER), Proyecto Interreg IIIB BIOPOLIS, Fundación del Instituto Canario de Investigación del Cáncer (FICIC), Cabildo de Gran Canaria, Cabildo de Tenerife and La Caja de Canarias, and Proyecto Estructurante "Integración de los grupos de investigación en Ciencias de la Salud entorno al estudio de la obesidad y el síndrome metabólico con un enfoque molecular, celular, fisiopatológico, epidemiológico y psicosocial", ULPGC, Gobierno de Canarias.

Ethics approval This study was conducted with the approval of the University of Las Palmas de Gran Canaria. 
Table 4 Body composition, anthropometrics, physical activity and fitness in men harbouring the microsatellite combinations $\mathrm{CAG}_{\mathrm{L}}+\mathrm{GGN}_{\mathrm{L}^{\prime}}$ $\mathrm{CAG}_{\mathrm{S}}+\mathrm{GGN}_{\mathrm{S}^{\prime}} \mathrm{CAG}_{\mathrm{S}}+\mathrm{GGN}_{\mathrm{L}}$ and $\mathrm{CAG}_{\mathrm{L}}+\mathrm{GGN}_{\mathrm{S}}$ (mean $\pm \mathrm{SD}$ )

\begin{tabular}{|c|c|c|c|c|c|c|c|c|}
\hline & $\mathrm{CAG}_{\mathrm{L}}+\mathrm{GGN}_{\mathrm{L}}$ & n & $\mathrm{CAG}_{\mathrm{S}}+\mathrm{GGN}_{\mathrm{S}}$ & n & $\mathbf{C A G}_{\mathrm{S}}+\mathbf{G G N}_{\mathrm{L}}$ & $\mathbf{n}$ & $\mathrm{CAG}_{\mathrm{L}}+\mathrm{GGN}_{\mathrm{S}}$ & $\mathbf{n}$ \\
\hline Age & $29.9 \pm 8.1$ & 48 & $28.1 \pm 6.9$ & 87 & $28.5 \pm 8.5$ & 64 & $29.2 \pm 7.3$ & 83 \\
\hline Height $(\mathrm{cm})$ & $176.8 \pm 6.0$ & 48 & $176.0 \pm 5.2$ & 87 & $177.3 \pm 5.4$ & 64 & $177.3 \pm 5.8$ & 83 \\
\hline Body mass (kg) & $80.0 \pm 12.8$ & 48 & $76.9 \pm 9.9$ & 87 & $78.3 \pm 9.4$ & 64 & $78.2 \pm 9.7$ & 83 \\
\hline Lean body mass (kg) & $59.6 \pm 5.3$ & 48 & $58.5 \pm 6.2$ & 87 & $59.9 \pm 5.2$ & 64 & $60.3 \pm 5.5$ & 83 \\
\hline Lean mass arms $(\mathrm{kg})$ & $6.7 \pm 0.8$ & 48 & $6.5 \pm 1.0$ & 87 & $6.7 \pm 0.9$ & 64 & $6.8 \pm 0.9$ & 83 \\
\hline Lean mass legs $(\mathrm{kg})$ & $19.6 \pm 2.0$ & 48 & $19.5 \pm 2.4$ & 87 & $20.1 \pm 2.2$ & 64 & $19.9 \pm 2.1$ & 83 \\
\hline Lean mass extremities $(\mathrm{kg})$ & $26.3 \pm 2.7$ & 48 & $25.9 \pm 3.3$ & 87 & $26.8 \pm 2.9$ & 64 & $26.7 \pm 2.7$ & 83 \\
\hline Lean mass extremties $/ \mathrm{Ht}^{2}\left(\mathrm{~kg} / \mathrm{m}^{2}\right)$ & $8.4 \pm 0.8$ & 48 & $8.4 \pm 0.9$ & 87 & $8.5 \pm 0.8$ & 64 & $8.5 \pm 0.8$ & 83 \\
\hline Sports history & $9.2 \pm 5.5$ & 47 & $8.1 \pm 6.6$ & 84 & $7.6 \pm 6.0$ & 61 & $7.5 \pm 5.2$ & 81 \\
\hline \multicolumn{9}{|l|}{ Jumping tests } \\
\hline SJJH (m) & $0.28 \pm 0.05$ & 44 & $0.30 \pm 0.05$ & 76 & $0.30 \pm 0.06$ & 57 & $0.29 \pm 0.05$ & 74 \\
\hline SJWmax (w) & $3438 \pm 577$ & 39 & $3365 \pm 537$ & 59 & $3425 \pm 561$ & 35 & $3423 \pm 502$ & 59 \\
\hline SJWmax/MML (w/kg) & $175.4 \pm 20.3$ & 39 & $174.1 \pm 19.2$ & 59 & $172.6 \pm 18.1$ & 35 & $170.0 \pm 18.3$ & 59 \\
\hline CMJJH (m) & $0.31 \pm 0.06$ & 44 & $0.34 \pm 0.07$ & 77 & $0.33 \pm 0.06$ & 57 & $0.33 \pm 0.05$ & 74 \\
\hline MVC/MML $(\mathrm{kg} / \mathrm{kg})$ & $5.3 \pm 1.1$ & 44 & $5.5 \pm 1.1$ & 74 & $5.2 \pm 0.9$ & 52 & $5.5 \pm 0.9$ & 67 \\
\hline \multicolumn{9}{|l|}{ Running tests } \\
\hline $\mathrm{T}_{30 \mathrm{~m}}(\mathrm{~s})$ & $4.56 \pm 0.37$ & 47 & $4.50 \pm 0.23$ & 84 & $4.52 \pm 0.28$ & 63 & $4.56 \pm 0.31$ & 78 \\
\hline $\mathrm{T}_{300 \mathrm{~m}}(\mathrm{~s})$ & $51.9 \pm 12.5$ & 47 & $49.4 \pm 6.1$ & 85 & $50.2 \pm 8.3$ & 63 & $50.0 \pm 8.5$ & 76 \\
\hline \multicolumn{9}{|l|}{ Maximal aerobic power } \\
\hline $\mathrm{VO}_{2} \max (\mathrm{ml} / \mathrm{kg} / \mathrm{min})$ & $46.7 \pm 8.3$ & 44 & $46.9 \pm 8.2$ & 81 & $47.1 \pm 7.6$ & 61 & $48.3 \pm 6.3$ & 80 \\
\hline
\end{tabular}

All $p>0.10$ after accounting for multiple comparisons (Bonferroni post hoc test).

CMJJH, jumping height in countermovement jumps; CMJWmax, maximal power in countermovement jumps; CMJWmax/MML, maximal power in countermovement jumps per kg of muscle mass in the lower extremities; Ht, height; MVC, maximal isometric force in the squatting position; SJJH, jumping height in squat jumps; SJWmax, maximal power in squat jumps; $S J W m a x / M M L$, maximal power in squat jumps per kg of muscle mass in the lower extremities (MML); $T_{30 \mathrm{~m}}$ and $T_{300 \mathrm{~m}}$ running time in the 30 and $300 \mathrm{~m}$ running sprint, respectively.

Provenance and peer review Not commissioned; externally peer reviewed.

Patient consent Obtained.

\section{REFERENCES}

1. Pedersen BK. Body mass index-independent effect of fitness and physical activity for all-cause mortality. Scand J Med Sci Sports 2007;17:196-204.

2. Silventoinen K, Magnusson PK, Tynelius P, et al. Heritability of body size and muscle strength in young adulthood: a study of one million Swedish men. Genet Epidemiol 2008;32:341-9.

3. Sun G, Gagnon J, Chagnon YC, et al. Association and linkage between an insulinlike growth factor-1 gene polymorphism and fat free mass in the HERITAGE Family Study. Int J Obes Relat Metab Disord 1999;23:929-35.

4. Van Pottelbergh I, Goemaere S, Nuytinck L, et al. Association of the type I collagen alpha1 Sp1 polymorphism, bone density and upper limb muscle strength in community-dwelling elderly men. Osteoporos Int 2001;12:895-901.

5. De Mars G, Windelinckx A, Beunen G, et al. Polymorphisms in the CNTF and CNTF receptor genes are associated with muscle strength in men and women. J App/ Physio/ 2007;102:1824-31.

6. Roth SM, Schrager MA, Lee MR, et al. Interleukin-6 (IL6) genotype is associated with fat-free mass in men but not women. J Gerontol A Biol Sci Med Sci 2003;58:B1085-8

7. Roth SM, Zmuda JM, Cauley JA, et al. Vitamin D receptor genotype is associated with fat-free mass and sarcopenia in elderly men. J Gerontol A Biol Sci Med Sci 2004;59:10-15.

8. Schrager MA, Roth SM, Ferrell RE, et al. Insulin-like growth factor-2 genotype, fat-free mass, and muscle performance across the adult life span. J App/ Physiol 2004;97:2176-83.

9. Pistilli EE, Gordish-Dressman H, Seip RL, et al. Resistin polymorphisms are associated with muscle, bone, and fat phenotypes in white men and women. Obesity (Silver Spring) 2007;15:392-402.

10. Walsh S, Zmuda JM, Cauley JA, et al. Androgen receptor CAG repeat polymorphism is associated with fat-free mass in men. J App/ Physiol 2005;98:132-7.

11. Navarro D, Luzardo OP, Fernández L, et al. Transition to androgen-independence in prostate cancer. J Steroid Biochem Mol Biol 2002;81:191-201.

12. González A, Javier Dorta F, Rodriguez G, et al. Increased risk of breast cancer in women bearing a combination of large CAG and GGN repeats in the exon 1 of the androgen receptor gene. Eur J Cancer 2007;43:2373-80.
13. Rodríguez G, Bilbao C, Ramírez R, et al. Alleles with short CAG and GGN repeats in the androgen receptor gene are associated with benign endometrial cancer. Int J Cancer 2006;118:1420-5.

14. González Hernández A, Cabrera de León A, Dominguez Coello S, et al. Serum resistin and polymorphisms of androgen receptor GAGn and GGNn and aromatase TTTAn. Obesity (Silver Spring) 2008;16:2107-12.

15. Yong EL, Lim J, Qi W, et al. Molecular basis of androgen receptor diseases. Ann Med 2000;32:15-22.

16. Lee DK, Chang C. Endocrine mechanisms of disease: Expression and degradation of androgen receptor: mechanism and clinical implication. J Clin Endocrinol Metab 2003;88:4043-54.

17. Hakimi JM, Schoenberg MP, Rondinelli RH, et al. Androgen receptor variants with short glutamine or glycine repeats may identify unique subpopulations of men with prostate cancer. Clin Cancer Res 1997;3:1599-608.

18. Ding D, Xu L, Menon M, et al. Effect of GGC (glycine) repeat length polymorphism in the human androgen receptor on androgen action. Prostate 2005;62:133-9.

19. Altuwaijri S, Lee DK, Chuang KH, et al. Androgen receptor regulates expression of skeletal muscle-specific proteins and muscle cell types. Endocrine 2004;25:27-32.

20. Santiago C, Ruiz JR, Muniesa CA, et al. Does the polygenic profile determine the potential for becoming a world-class athlete? Insights from the sport of rowing. Scand J Med Sci Sports 2009;20:e88-94.

21. Ruiz JR, Gómez-Gallego F, Santiago C, et al. Is there an optimum endurance polygenic profile? J Physiol (Lond) 2009;587:1527-34.

22. Gómez-Gallego F, Santiago C, González-Freire M, et al. Endurance performance: genes or gene combinations? Int J Sports Med 2009;30:66-72.

23. Perez-Gomez J, Olmedillas $\mathrm{H}$, Delgado-Guerra S, et al. Effects of weight lifting training combined with plyometric exercises on physical fitness, body composition, and knee extension velocity during kicking in football. App/ Physiol Nutr Metab 2008;33:501-10.

24. Calbet JA, Moysi JS, Dorado C, et al. Bone mineral content and density in professional tennis players. Calcif Tissue Int 1998;62:491-6.

25. Guerra B, Fuentes T, Delgado-Guerra S, et al. Gender dimorphism in skeletal mus cle leptin receptors, serum leptin and insulin sensitivity. PLOS ONE 2008;3:e3466.

26. Kim J, Wang Z, Heymsfield SB, et al. Total-body skeletal muscle mass: estimation by a new dual-energy X-ray absorptiometry method. Am J Clin Nutr 2002; 76:378-83.

27. Ara I, Vicente-Rodríguez G, Jimenez-Ramirez J, et al. Regular participation in sports is associated with enhanced physical fitness and lower fat mass in prepubertal boys. Int J Obes Relat Metab Disord 2004;28:1585-93. 


\section{Take home message}

The length of $C A G$ and $G G N$ repeat of the $A R$ gene do not appear to influence lean mass or fitness in young men. Additional studies are required to test if men harbouring the combination $C A G_{S}$ and $G G N_{S}$ have more jumping capacity.

28. Vicente-Rodriguez G, Ara I, Perez-Gomez J, et al. High femoral bone mineral density accretion in prepubertal soccer players. Med Sci Sports Exerc 2004;36:1789-95.

29. Calbet JA, De Paz JA, Garatachea N, et al. Anaerobic energy provision does not limit Wingate exercise performance in endurance-trained cyclists. J Appl Physiol 2003;94:668-76.

30. Léger LA, Mercier D, Gadoury C, et al. The multistage 20 metre shuttle run test for aerobic fitness. J Sports Sci 1988;6:93-101.
31. Lietzke MH. Relation between weightlifting totals and body weight. Science 1956; 124:486-7.

32. Kyle UG, Genton L, Hans D, et al. Total body mass, fat mass, fat-free mass, and skeletal muscle in older people: cross-sectional differences in 60-year-old persons. J Am Geriatr Soc 2001;49:1633-40.

33. Ara I, Vicente-Rodriguez G, Perez-Gomez J, et al. Influence of extracurricular sport activities on body composition and physical fitness in boys: a 3-year longitudinal study. Int J Obes (Lond) 2006;30:1062-71.

34. Bosco C, Komi PV, Tihanyi J, et al. Mechanical power test and fiber composition of human leg extensor muscles. Eur J Appl Physiol Occup Physiol 1983;51:129-35.

35. Perez-Gomez J, Rodriguez GV, Ara I, et al. Role of muscle mass on sprint performance: gender differences? Eur J Appl Physiol 2008;102:685-94.

36. Cristea A, Korhonen MT, Häkkinen K, et al. Effects of combined strength and sprint training on regulation of muscle contraction at the whole-muscle and single-fibre levels in elite master sprinters. Acta Physiol (Oxf) 2008;193:275-89.

37. Schantz P, Randall-Fox E, Hutchison W, et al. Muscle fibre type distribution, muscle cross-sectional area and maximal voluntary strength in humans. Acta Physiol Scand 1983;117:219-26.

38. Sinha-Hikim I, Artaza J, Woodhouse L, et al. Testosterone-induced increase in muscle size in healthy young men is associated with muscle fiber hypertrophy. Am J Physiol Endocrinol Metab 2002;283:E154-64. 
BJSM

\section{Androgen receptor gene polymorphisms lean mass and performance in young men}

Amelia Guadalupe-Grau, F Germán Rodríguez-González, Cecilia Dorado, et al.

Br J Sports Med 2011 45: 95-100 originally published online July 16, 2009

doi: $10.1136 /$ bjsm.2009.060285

Updated information and services can be found at:

http://bjsm.bmj.com/content/45/2/95.full.html

These include:

References This article cites 38 articles, 11 of which can be accessed free at: http://bjsm.bmj.com/content/45/2/95.full.html\#ref-list-1

Article cited in:

http://bjsm.bmj.com/content/45/2/95.full.html\#related-urls

Email alerting Receive free email alerts when new articles cite this article. Sign up in service the box at the top right corner of the online article.

Notes

To request permissions go to:

http://group.bmj.com/group/rights-licensing/permissions

To order reprints go to:

http://journals.bmj.com/cgi/reprintform

To subscribe to BMJ go to:

http://group.bmj.com/subscribe/ 